\title{
MEASURING THE EFFICIENCY OF POLISH MUNICIPALITIES - DATA ENVELOPMENT ANALYSIS APPROACH ${ }^{1}$
}

Tomasz Skica, Małgorzata Leśniowska-Gontarz, Katarzyna Miszczyńska

\section{Abstract}

The aim of the paper is to build a ranking of municipalities due to their level of efficiency from the development point of view. According to the aim, it is possible to find out which indicators are crucial for the efficiency of municipalities in terms of sustainability. The research study involved DEA (Data Envelopment Analysis) approach. Conducted research study covered 2044 Polish municipalities in the year 2016. The ranking of Polish municipalities was prepared with the use of the DEA model. The DEA method made it possible to set goals for inefficient municipalities, which should follow and regularly evaluate the progress in the implementation of their aims. Inefficient municipalities can improve their efficiency following the technological example of chosen benchmarks.

Keywords: Data Envelopment Analysis (DEA), municipalities, sustainable development

JEL Codes: $H 70, H 72, H 75, I 15$

\section{INTRODUCTION}

It is the society of a given local unit that is an important receiver of local development and it is its standard of living that is the ultimate goal of the undertaken efforts (within the framework of development policy). One of the most important aspects of the development of the local entities is therefore social development, expressed in quality of life of its inhabitants. On the background of scientific research, sustainable development is a comprehensive concept and means a continuous improvement in the quality of life, both present and future generations, achieved by shaping the right proportions in managing human, anthropogenic and natural capital. According to the above, proper delivery of public services by municipalities is a key indicator in developing the quality of life of the society at the local level. Measuring efficiency of municipalities has become in recent times

Tomasz Skica, PhD
Institute for Financial Research and Analyses
University of Information Technology and
Management in Rzeszow, Poland
E-mail: tskica@wsiz.rzeszow.pl
Małgorzata Leśniowska-Gontarz, MSc
Institute for Financial Research and Analyses,
University of Information Technology and
Management in Rzeszow, Poland
E-mail: mlesniowska@wsiz.rzeszow.pl
Katarzyna Miszczyńska, PhD
Department of Economics and Sociology
University of Lodz, Poland
E-mail: katarzyna.miszczynska@uni.lodz.pl

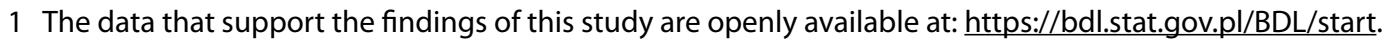


a major subject of discuss both for practitioners and authorities. It is important in the context of search for performance benchmarks needed to plan targets defining liability measures helpful for decision-making at higher level of government. Furthermore, the topic of measuring efficiency of municipalities is crucial for citizens and scholars more interested in understanding purposes of public spending raise and determinants of limited efficiency (Corrado lo Storto 2013).

The conducted research study aimed to verify the hypothesis about the existence of a relationship between the development of municipalities and the (relative) efficiency of its functioning.

The article consists of the following parts: literature review, sample and methodology, results and discussion. Literature review includes analysis of research studies discussing the efficiency of municipalities in the context of sustainable development. The part called sample and methodology gives a brief description of chosen methodology and delivers the information about selected decision-making units. The last part of article shows the results of undertaken research study.

The contribution of this paper to the literature is connected with the number of the analyzed units. The sample is made of 2044 municipalities (including: urban, urban-rural and rural) while previous research studies mostly concentrated on chosen Polish regions and municipalities. The proposed research study covers all regions of Poland. Furthermore, conducted research study uses a wide range of inputs and outputs, that have never been seen before.

\section{LITERATURE REVIEW}

In recent years the topic of local development has attracted growing interest in research studies. Local development is basically connected with a multi-dimensional idea of transform bringing jointly financial, educational, societal and environmental dimensions - with improvement observed in the gaps between mentioned dimensions. It may be seen as a technique which allows $s$ to improve level of life, support or accelerate empowerment of citizens, rise or preserve local resources, overcome market failures, strength solidity, and define and deliver grass-root expansion projects (Kisman and Tasar 2014, p. 1690).

Myna (1998) distinguishes five groups of initiators of local development: local authorities, ecological lobbies, social and cultural societies, investors and local communities. Sztando (1998) assumes that the local government is expected to be the driving force of local development while representing the widest possible range of interests of the local community.

Local government has some tools to complete consisting of determining life surroundings that are valuable to the inhabitants and the function of business entities. To achieve this purpose it undertakes various activities, and uses legal and economic instruments (Sierak 2016, p. 61). Local government creates a scheme which holds as one all its different players (public and private business entities, society scientific research institutions and development agencies), in a productive tension which makes maximum use of all accessible resources, capability and experience (Clark et al. 2010, p. 130).

Local government units frequently are criticized of mismanagement or even a waste of public resources. An effort to modify this state of affairs is the reorganization of public sector carried out by individual countries in the world with a common aim even though expected at increasing the efficiency of the public entities including municipalities (Zioło 2012).

Research studies on the efficiency of economic entities were implemented by M. J. Farell. In his opinion, the efficiency depends principally on the technical (technological) and allocation (price) indicators. According the above, Farell postulated to measure technical and allocative efficiency. Technical efficiency reflects the ability of an entity to achieve maximum outputs at given inputs while allocative efficiency is the ability to use an optimum set of inputs given their prices and available production technology (Farell 1957, pp. 253-290).

In the terminology used in economics, efficiency is usually calculated as the ratio of an effect that has been obtained to a given production factor engaged. Efficiency informs us about the cost of achieving a given goal. Each rationally operating entity strives to act efficiently by either trying to maximise the effects given limited resources or by minimising the use of resources to arrive at concrete effects (Opolski, Podgórska and Leśniowska-Gontarz 2018, p. 84).

The assessment of the efficiency of public finance sector entities can be conducted using both one-dimensional and multidimensional methods (Ziębicki 2014). In the case of assessment of the efficiency of local government units, it is necessary to compare many of the effects of their activities, which will result in the need to use methods that take into account the possibility of aggregating criteria. In the source literature on the subject, both parametric methods (e.g. OLS - Ordinary Least Squares, SFA - Stochastic Frontier Analysis or TFA - Thick Frontier Approach) and nonparametric methods (e.g. DEA - Data Envelopment Analysis; FDH - Free Disposal Hull) are used for multidimensional measurement of entities' effectiveness 
(Geys and Moesen 2009; Ziębicki 2014). DEA method was used to measure the efficiency of public sector entities in many research projects. The first stream in scientific research studies evaluating the efficiency of single services delivered by municipalities, i.e. library services (Worthington 1999), water management (Pereira and Marques 2017); (Alsharif et al. 2008), transport services (Hajduk 2018), solid waste management (Huang et al. 2008) or public health services (Vitezić 2016; Kirigia 2008).

Second stream in scientific research studies is to measure overall efficiency of municipalities. Yuan et al. (2015) applied DEA technique to check the capacity of 65 Chinese cities to respond to natural disasters, Corrado lo Storto (2016) have prepared ranking of cities based on ecological efficiency and Yang et al. (2016) used this method to approximate the sustainability of cities in Taiwan. Miszczyński (2013) evaluated development performance using a data set covering 128 Polish cities. Furthermore, researchers have leaded a number of studies that cover municipalities in different countries like Belgium (De Borger and Kerstens 1996), Japan (Nijkamp and Suzuki 2009), Brazil (Sampaio de Sousa et al. 2005), China (Sueyoshi and Yuan 2015), Australia (Drew et al. 2015). Sueyoshi and Yuan (2015) measure the efficiency of municipality cities divided into four different kinds of local classifications. The empirical outcomes point out that the Chinese government should allocate its economic capital to cities, which are located in the northwest region and strengthen stricter regulation on energy consumptions for environmental prevention in major cities. Drew et al. (2015) demonstrate the effect of specification decisions on public policy made by employing four models of Australian municipal efficiency.

Furthermore, additional creative ways to use performance analysis have emerged that include issues such as changes in productivity over time and the impact of ownership and institutions on efficiency (Jacobs et al. 2013, p. 28).

\section{DATA AND METHODOLOGY}

\section{1 Methodology}

Charnes, Cooper and Rhodes (1978) proposed a nonparametric Data Envelopment Analysis method to evaluate the effectiveness. In their pioneering work (1978), they introduced the term Decision-Making Units (DMUs), defining the decision-making entity covered by the research study while the subject of the analysis is the effectiveness through which DMU transforms the inputs into outputs. This method was quickly recognized, especially in the case of the evaluating the effectiveness of service and non-profit entities (Kudła 2011, p. 47). The first DEA approach was called CCR (Charnes et al.1978) model, then BCC model was investigated (Banker et al.1984).

DEA models are divided into two main orientations: input-oriented and output-oriented. First one, input-oriented model is used to check if a DMUs under assessment can cut its inputs while keeping the outputs at their existing levels. Second one, outputoriented model is applied to check if a DMUs can enlarge its outputs while keeping the inputs at their unchanged levels.

In the DEA model, the practical form of the efficient production frontier is not pre-established. What is more, the functional correlation between inputs and outputs it does not required to be predetermined. It is intended via a mathematical programming model as well as an econometric method implemented to a sample of observed data. Using this set of the observed data, a frontier envelopment surface is determined and the DMUs (in this case local municipalities) that lie on that surface are called productively efficient and are assigned a value or an efficiency score equal to one. Alternatively, the DMUs that do not lie on that surface are considered productively inefficient and an inefficiency score of less than one will then be calculated for each one of them (Murillo-Zamorano 2004; Ramanathan 2003).

DEA application allows for the creation of a ranking of DMUs, indicating the units that could achieve higher outputs at given inputs. The DEA makes it possible to evaluate the activities of individual units relatively to the others, as a result, model units are designated and according to this way of operation and features can be covered by other DMUs. Thus, it means that it is possible to set goals for which the DMUs should strive and regularly evaluate the progress in its implementation. DMUs are classified by score, when the result is equal to 1.0 DMU is efficient, in the other case when DMUs have efficiency results smaller than 1.0 , it is inefficient unit.

During assessment, the efficiency result of a DMU is considered by the combination of a position of DEA efficient DMU(s), which shape a part of the segments on the efficiency frontier. The DMUs recognized as efficient are not equal among themselves in the CCR and other DEA models as well. It is observed that some DEA researchers initiated a new stream called superefficiency to grade the DEA efficient DMUs and developed different models (Shanling et al. 2007, p. 638).

According to the above, a stream in scientific research studies is created where researchers are concentrating on classification just DEA efficient DMUs recognized on the outcomes gained either from CCR 
(Charnes, Cooper, Rhodes) or BCC models (Banker, Charnes, Cooper model). The research study in this stream was first developed by Andesen and Petersen (1993), who graded DEA efficient DMUs in this way that efficient DMUs may have efficiency score higher than 1. This kind of stream became well-known and many scientists go after this theory (Sieford and Zhu1999; Mehrabian et al.1999; Tone 2001).

Even though the super-efficiency approach is used grade extreme DEA efficient DMUs gained by the CCR model, it can be applied in order to assess efficient units straightforwardly. This means that without the CCR model solution, researcher can grade efficient DMUs by resolving only the super-performance model. The main rule is that efficient DMUs have super-efficiency result higher than 1 as well as equal to1, while inefficient DMUs have super-efficiency result less than 1 (Shanling et al. 2007, p. 640).

Main assumption: there are $\mathrm{n}$ homogeneous DMUs in which all the DMUs use $m$ inputs $x_{i j}(i=1, \ldots, m)$ to produce $s$ outputs $y_{\mathrm{rj}}(\mathrm{r}=1, \ldots, \mathrm{s})$. It is assumed that

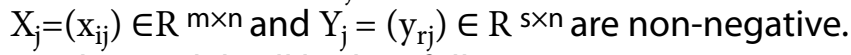

The model will look as follows:

$$
\begin{gathered}
\text { Minimize } 1+\frac{1}{m} \sum_{i=1}^{m} \frac{s_{i 2}^{+}}{R_{i}^{-}} \\
\text {Subject to } \sum_{j=1}^{n} \lambda_{j} x_{i j}+s_{i 1}^{-}-s_{i 2}^{+}=x_{i 0}, \quad \mathrm{i}=1, \ldots, \mathrm{m}, \mathrm{j} \neq 0 \\
\sum_{j=1}^{n} \lambda_{j} y_{r j}-s_{r}^{+}=y_{r 0} \quad \mathrm{r}=1, \ldots, \mathrm{s}, \mathrm{j} \neq 0 \\
\lambda_{j}, s_{i 1}^{-}, s_{i 2}^{+}, s_{r}^{+} \geq 0, \quad \forall j, i, r,
\end{gathered}
$$

where Ri is upper limit for all $i$ th inputs together with $i$ th input of evaluating DMU i.e $R_{i}^{-}=\max _{\mathrm{j}}\left(\mathrm{x}_{\mathrm{ij}}\right)$

$R_{i}^{-} \mathrm{t}$ is constantly positive for the reason that it is equal to zero, it means no DMU used the input $i$.

Furthermore, for every $\mathrm{DMU}_{0}$ being evaluated, the reason of the model is to decrease the unity plus the average ratio of the second input slacks over the greatest inputs along with all DMUs. Given that the primary and the next pieces are unitless, the objective function of the model is unit invariant. The primary constraint gives the input $i$ of $\mathrm{DMU}_{0}$ to enlarge by $s_{i 2}^{+}$ or reduce by $s_{i 1}^{-}$. One may expect it is feasible to apply a free variable $s$ as a substitute of both slack variables, $s_{i 2}^{+}$and $s_{i 1}^{-}$in input constraint, while implementing free variable $s$ conducts to dual infeasibility of the super-efficiency model which purposes difficulty to the model. It can be interpreted as follows: "If we eliminate $\mathrm{DMU}_{0}$, we should make use of an extra $s_{i 2}^{+}$ units of $i$ th resource so then a combination of the rest of DMUs can create the output of excluding DMU equal to $\mathrm{y}_{\mathrm{r} 0}$ ". The next limitation assumes that the output $r$ of $\mathrm{DMU}_{0}$ can be simply enlarge by $s_{r}^{+}$. It should be noted that the non-negative linear combinations mutually constraints 1 and 2 as well do not take account of $\mathrm{DMU}_{0}$. It should be added, that if the most favorable objective value of this approach is larger than 1, $\mathrm{DMU}_{0}$ which is DEA efficient under CCR model is super-efficient under above model as well. If not, $\mathrm{DMU}_{0}$ is not super-efficient. Therefore, it is likely just to resolving super-efficiency approach 1 for standing efficient entities without solving the CCR model (Shanling et al. 2007, p. 641).

The non-parametric approach that include Data Envelopment Analysis (DEA) has more than a few advantages. Benefit of the DEA technique is the fact that it is not necessary to know how inputs are transformed into effects, the essence is to have knowledge of the amount of inputs and outcomes to assess whether a given entity is or is not in the group of effective units. Furthermore, DEA is a mathematical programming method that expands the Farell's efficiency measure (1957) to a multiple outputs and inputs as well, and uses extremely weak assumptions linked to the assessment of the practical production function changing inputs into outputs for each DMU Corrado lo Storto (2013, p. 347).

However, the inference made using the DEA method inevitably has its drawbacks. First, because of the fact that that a separate optimization task is carried out for each DMU, the obtained results of technical efficiency assessments are relative values that cannot be transformed into absolute categories. DEA method shows high sensitivity to changes in the number of inputs and results, as also changes in the size of the group or DMU units, which affects the result efficiency (Jewczak and Żółtaszek 2011, p.197). What is more, among the most important disadvantages of the DEA method, apart from the relative nature of the analysis, is its sensitivity to atypical DMU and atypical variables and redundancy of objects considered fully effective (Nowak 2013, p. 103; Czyż-Gwizdała 2013, p. 112; Guzik 2009, p. 76).

The analysis of the efficiency of Polish municipalities in the context of sustainable development was carried out by means of the output - oriented superefficiency Charnes, Cooper, Rhodes models (Se-CCR ${ }^{2}$ with the assumption of constant economies of scale. It was mentioned in literature review that sustainable development expressing itself in local development, is based on a multi-dimensional concept. This idea brings together economic, social, cultural and environmental dimensions. Thus, the selection of inputs and outputs covers definitions of local development included in literature review. Inputs and outputs represent dimensions which have great impact on 
Table 1: Inputs and outputs included in research study

\begin{tabular}{|c|c|}
\hline Inputs & Outputs \\
\hline $\begin{array}{l}\text { 1. Population at post-working age per } 100 \text { persons of working age } \\
\text { 2. Density of population at } 1 \text { km2 } \\
\text { 3. Number of advices provided in primary healthcare } \\
\text { 4. Apartments per } 1000 \text { inhabitants } \\
\text { 5. Total Employment } \\
\text { 6. Registered unemployed } \\
\text { 7. Water consumption from water network per } 1 \text { inhabitant } \\
\text { 8. Total expenditure of municipalities per } 1 \text { inhabitant } \\
\text { 9. Share of investment expenditures of municipalities in total } \\
\text { 10. Number of advices provided in outpatient health care } \\
\text { 11. Outpatient clinics for } 10,000 \text { inhabitants } \\
\text { 12. Built-up and urbanized land together (in ha) } \\
\text { 13. Expenditure on Agriculture and hunting (in PLN) } \\
\text { 14. Expenditure on Municipal management and environmental protec- } \\
\text { tion (in PLN) } \\
\text { 15. Expenditure on Transport and communication (in PLN) } \\
\text { 16. Expenditure on Housing (in PLN) } \\
\text { 17. Expenditure on Public administration (in PLN) } \\
\text { 18. Expenditure on Public safety and fire protection (in PLN) } \\
\text { 19. Expenditure on Public debt service (in PLN) } \\
\text { 20. Expenditure on Education and upbringing (in PLN) } \\
\text { 21. Expenditure on Health care (in PLN) } \\
\text { 22. Expenditure on Social assistance (in PLN) } \\
\text { 23. Expenditure on Educational care (in PLN) } \\
\text { 24. Expenditure on Culture and protection of national heritage (in PLN) } \\
\text { 25. Expenditure on Physical education (in PLN) }\end{array}$ & $\begin{array}{l}\text { 1. Live births per } 1000 \text { inhabitants } \\
\text { 2. People below the income criterion us- } \\
\text { ing environmental social protection } \\
\text { 3. Percentage of people using the water } \\
\text { supply network in total population } \\
\text { (in\%) } \\
\text { 4. Percentage of people using the sewer- } \\
\text { age network in the total population } \\
\text { (in\%) } \\
\text { 5. Children per } 1 \text { branch in kindergarten } \\
\text { 6. Gross enrollment rate. Primary schools } \\
\text { 7. Gross enrollment rate. Secondary } \\
\text { schools } \\
\text { 8. Readers of public libraries per } 1000 \\
\text { inhabitants } \\
\text { 9. Newly registered entities per } 10 \text { 000 } \\
\text { working-age population } \\
\text { 10. Area of forest land (in ha) } \\
\text { 11. Mixed waste from households col- } \\
\text { lected during the year per } 1 \text { inhabitant } \\
\text { (in kg) } \\
\text { 12. Electoral attendance for municipal } \\
\text { councils (\% of commune population) } \\
\text { 13. Foundations, associations and social } \\
\text { organizations per } 10 \text { o00 inhabitants } \\
\text { 14. Total income per } 1 \text { inhabitant }\end{array}$ \\
\hline
\end{tabular}

Source: Own elaboration based on Local Data Bank (LDB).

improvement of quality of life of local communities. What is more, all inputs and outputs represented the functioning of municipalities. Table 1 shows inputs and outputs used in research study.

The analysis was conducted for the year 2016 based on 25 inputs and 14 outputs assigned to relevant areas considered as part of the analysis of the sustainable development of municipalities. The study covered 2044 municipalities (urban, urban-rural and rural).

\section{II.2 Results and discussion}

In the first step of the analysis the homogeneity of the set of objects was tested. The study was based on the exclusion of municipalities (later known as DMUs) outliers from the set of DMUs, from the perspective of the value of ranking indicators. Objects characterized by values significantly exceeding certain levels of efficiency are unusual (heterogeneous) comparing to the others. From the group of 2044 analysed objects 21 DMUs (objects) were excluded due to the results of homogeneity test. After this procedure, the SE-CCR model was calculated one more time. The results of the model brought $85 \%$ of efficient municipalities in terms of sustainable development. These outcomes verify positively hypothesis that there is a correlation between the development of municipalities and the (relative) efficiency of its functioning. Only 15\% of analysed municipalities were classified as inefficient. 1742 DMUs were efficient with maximum level of super-efficiency of $864 \%$.

Obtained results are in line with findings of Olejniczak (2018), Miszczyński (2013) and Łękawa (2012). These authors also tried to find the correlation between the development of municipalities and the efficiency of its activities. The conclusion for above mentioned research studies is that there is a relationship between the development of municipalities and the efficiency of its performance.

On the other hand, there can be found research study that is in the opposite to the postulates of the obtained findings. The studies conducted by Kobiałka and Kubik (2018) show that the amount of expenditure incurred on the studied spheres of investment activity of the analyzed communes does not translate into their efficiency. Detailed findings of conducted research study can be found below. 
Table 2: Selected efficiency scores of SE-CCR output-oriented model (efficient DMUs)

\begin{tabular}{|c|c|c|c|c|c|}
\hline $\begin{array}{c}\text { Super- } \\
\text { efficiency } \\
\text { ratio }\end{array}$ & Name & $\begin{array}{c}\text { Municipality } \\
\text { type }\end{array}$ & $\begin{array}{c}\text { Super- } \\
\text { efficiency } \\
\text { ratio }\end{array}$ & Name & $\begin{array}{c}\text { Municipality } \\
\text { type }\end{array}$ \\
\hline $864 \%$ & Ochotnica Dolna (2) & rural & $322 \%$ & Rychliki (2) & rural \\
\hline $794 \%$ & Szczyrk (1) & urban & $321 \%$ & Suchedniów (3) & urban-rural \\
\hline $786 \%$ & Grabica (2) & rural & $318 \%$ & Świdwin (2) & rural \\
\hline $736 \%$ & Łukowica (2) & rural & $316 \%$ & Bircza (2) & rural \\
\hline $668 \%$ & Boguty-Pianki (2) & rural & $316 \%$ & Stary Brus (2) & rural \\
\hline $661 \%$ & Krupski Młyn (2) & rural & $314 \%$ & Sucha Beskidzka (1) & urban \\
\hline $611 \%$ & Mielno (2) & rural & $313 \%$ & Goszczyn (2) & rural \\
\hline $604 \%$ & Radecznica (2) & rural & $313 \%$ & Nozdrzec (2) & rural \\
\hline $600 \%$ & Cisna (2) & rural & $312 \%$ & Rytro (2) & rural \\
\hline $575 \%$ & Kluki (2) & rural & $309 \%$ & Pęcław (2) & rural \\
\hline $570 \%$ & Górowo lławeckie (1) & urban & $309 \%$ & Biłgoraj (2) & rural \\
\hline $547 \%$ & Wieczfnia Kościelna (2) & rural & $308 \%$ & Grybów (1) & urban \\
\hline $547 \%$ & Brańsk (1) & urban & $307 \%$ & Hajnówka (1) & urban \\
\hline $522 \%$ & Nieszawa (1) & urban & $306 \%$ & Miasteczko Śląskie (1) & urban \\
\hline $518 \%$ & Bakałarzewo (2) & rural & $306 \%$ & Aleksandrów Kujawski (1) & urban \\
\hline $511 \%$ & Świnna (2) & rural & $305 \%$ & Zawidów (1) & urban \\
\hline $482 \%$ & Karpacz (1) & urban & $304 \%$ & Włocławek (1) & urban \\
\hline $453 \%$ & Moszczenica (2) & rural & $298 \%$ & Legionowo (1) & urban \\
\hline $452 \%$ & Dubicze Cerkiewne (2) & rural & $297 \%$ & Poręba (1) & urban \\
\hline $450 \%$ & Ostrowice (2) & rural & $294 \%$ & Grabów nad Pilicą (2) & rural \\
\hline $446 \%$ & Jejkowice (2) & rural & $293 \%$ & Budry (2) & rural \\
\hline $439 \%$ & Krasiczyn (2) & rural & $284 \%$ & Sidra (2) & rural \\
\hline $436 \%$ & Czorsztyn (2) & rural & $284 \%$ & Czarna (2) & rural \\
\hline $424 \%$ & Ślemień (2) & rural & $283 \%$ & Nawojowa (2) & rural \\
\hline $414 \%$ & Kamienica Polska (2) & rural & $280 \%$ & Jedlina-Zdrój (1) & urban \\
\hline $412 \%$ & Radziłów (2) & rural & $280 \%$ & Sławoborze (2) & rural \\
\hline $412 \%$ & Oleśnica (2) & rural & $279 \%$ & Dynów (2) & rural \\
\hline $401 \%$ & Podedwórze (2) & rural & $277 \%$ & Markusy (2) & rural \\
\hline $397 \%$ & Puszczykowo (1) & urban & $276 \%$ & Haczów (2) & rural \\
\hline $387 \%$ & Rypin (2) & rural & $275 \%$ & Raciąż (1) & urban \\
\hline $386 \%$ & Brok (3) & urban-rural & $275 \%$ & Dzierżoniów (2) & rural \\
\hline $383 \%$ & Świeradów-Zdrój (1) & urban & $272 \%$ & Wojciechów (2) & rural \\
\hline $383 \%$ & Stoczek Łukowski (1) & urban & $271 \%$ & Radków (2) & rural \\
\hline $379 \%$ & Radziemice (2) & rural & $268 \%$ & Boguszów-Gorce (1) & urban \\
\hline $370 \%$ & Płoskinia (2) & rural & $267 \%$ & Żelazków (2) & rural \\
\hline $366 \%$ & Wisła (1) & urban & $266 \%$ & Biały Bór (3) & urban-rural \\
\hline $363 \%$ & Łukowa (2) & rural & $266 \%$ & Kobyłka (1) & urban \\
\hline $360 \%$ & Chełmno (1) & urban & $265 \%$ & Gozdnica (1) & urban \\
\hline $357 \%$ & Duszniki-Zdrój (1) & urban & $264 \%$ & Ropa (2) & rural \\
\hline $353 \%$ & Świeszyno (2) & rural & $263 \%$ & Lipno (1) & urban \\
\hline $347 \%$ & Rewal (2) & rural & $263 \%$ & Godkowo (2) & rural \\
\hline $347 \%$ & Elbląg (2) & rural & $263 \%$ & Czeremcha (2) & rural \\
\hline $339 \%$ & Skórcz (1) & urban & $260 \%$ & Stara Kamienica (2) & rural \\
\hline $338 \%$ & Lipowa (2) & rural & $258 \%$ & Serokomla (2) & rural \\
\hline $337 \%$ & Uścimów (2) & rural & $255 \%$ & Sławków (1) & urban \\
\hline $330 \%$ & Domanice (2) & rural & $255 \%$ & Magnuszew (2) & rural \\
\hline $329 \%$ & Gościeradów (2) & rural & $254 \%$ & Brzostek (3) & urban-rural \\
\hline $329 \%$ & Mały Płock (2) & rural & $253 \%$ & Jarocin (2) & rural \\
\hline $327 \%$ & Łeba (1) & urban & $252 \%$ & Bytnica (2) & rural \\
\hline $326 \%$ & Skarżysko Kościelne (2) & rural & $252 \%$ & Międzyzdroje (3) & urban-rural \\
\hline
\end{tabular}

Source: Own elaboration.

The Table 2 presents the results of SE-CCR for selected and the most efficient municipalities with their efficiency scores. 
Map 1: Efficiency scores of SE-CCR output-oriented model for all included in research study municipalities

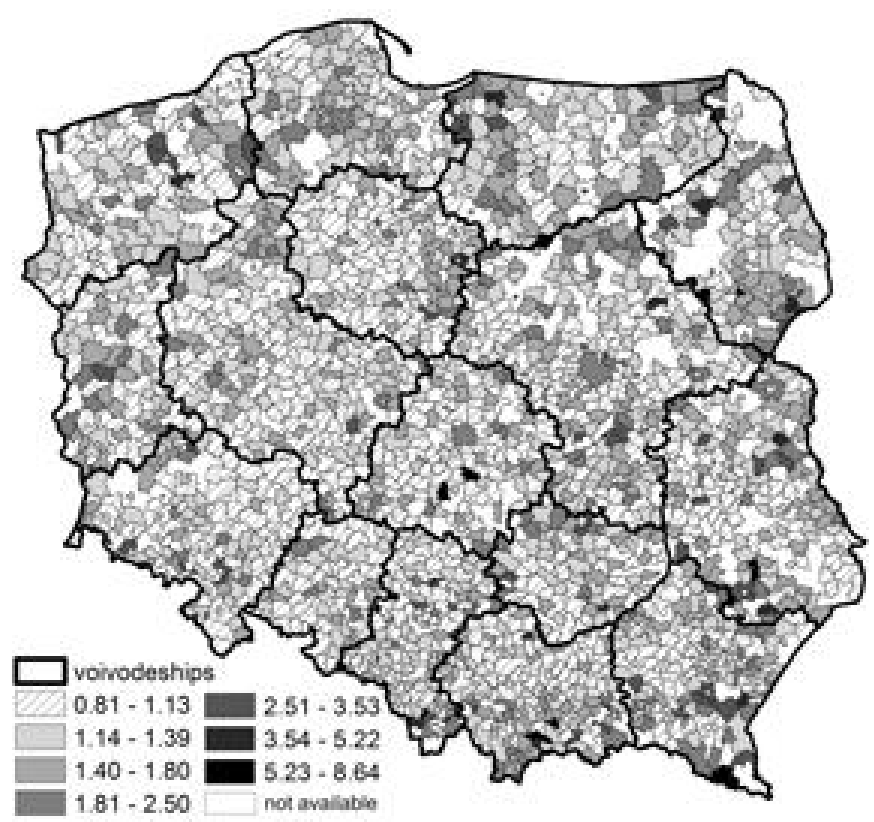

Source: Own elaboration.

As far as inefficient units are concerned on the basis of SE-CCR model 281 such units have been distinguished. The spread in the level of efficiency in this group did not vary significantly. To illustrate the number of units referring to individual value indicators, a compartmental series was created. The division into intervals was the result of the creation of a series interval, the construction of which was based on the classical theory of statistics. The results are presented in Table 3 and Figure 1.

According to the Figure 1 it can be easily seen that the majority of ineffective units were characterized by an efficiency index between $93 \%$ and $99 \%$. Only 19 units did not exceed the level of $90 \%$ of efficiency understood in the sense of the SE-CCR model.

A similar graph was created to illustrate the effective DMU. The maximum efficiency score did not
Table 3: Assignment of DMUs to intervals depending on the value of efficiency indicators for inefficient DMUs

\begin{tabular}{|c|c|c|c|}
\hline $\begin{array}{c}\text { Interval } \\
\text { denota- } \\
\text { tion }\end{array}$ & $\begin{array}{c}\text { Lower bound } \\
\text { (the efficiency } \\
\text { stores) }\end{array}$ & $\begin{array}{c}\text { Upper bound } \\
\text { (the efficiency } \\
\text { stores) }\end{array}$ & $\begin{array}{c}\text { Number } \\
\text { of DMUs }\end{array}$ \\
\hline I & 81 & 82,13 & 2 \\
\hline II & 82,13 & 83,25 & 0 \\
\hline III & 83,25 & 84,38 & 0 \\
\hline IV & 84,38 & 85,50 & 0 \\
\hline V & 85,50 & 86,63 & 5 \\
\hline VI & 86,63 & 87,75 & 1 \\
\hline VII & 87,75 & 88,88 & 4 \\
\hline VIII & 88,88 & 90,00 & 7 \\
\hline IX & 90,00 & 91,13 & 12 \\
\hline X & 91,13 & 92,25 & 12 \\
\hline XI & 92,25 & 93,38 & 18 \\
\hline XII & 93,38 & 94,50 & 28 \\
\hline XIII & 94,50 & 95,63 & 38 \\
\hline XIV & 95,63 & 96,75 & 39 \\
\hline XV & 96,75 & 97,88 & 37 \\
\hline XVI & 97,88 & 99,00 & 37 \\
\hline XVII & 99,00 & 100,00 & 17 \\
\hline
\end{tabular}

Source: Own elaboration.

exceed the level of $864 \%$. According to the results presented in Figure 2 a significant left skewness was observed. The first four intervals represent DMUs with efficiency scores from $168 \%$ to maximum of $864 \%$. Figure 2 presents frequency chart and Table 4 presents an assignment of DMUs to intervals depending on the value of efficiency indicators for efficient DMUs.

To make the analysis complete the shares of individual municipalities in all units within the effective and ineffective DMUs were designated. Details are presented in Figures 3 and 4. In the group of inefficient DMUs $45 \%$ of units are rural-urban, $39 \%$ - rural and $46 \%$ urban. In terms of efficient units, a great majority are rural (62\%), $25 \%$ - urban-rural and the rest constitute urban units.

Figure 1: Inefficient DMUs - frequency chart

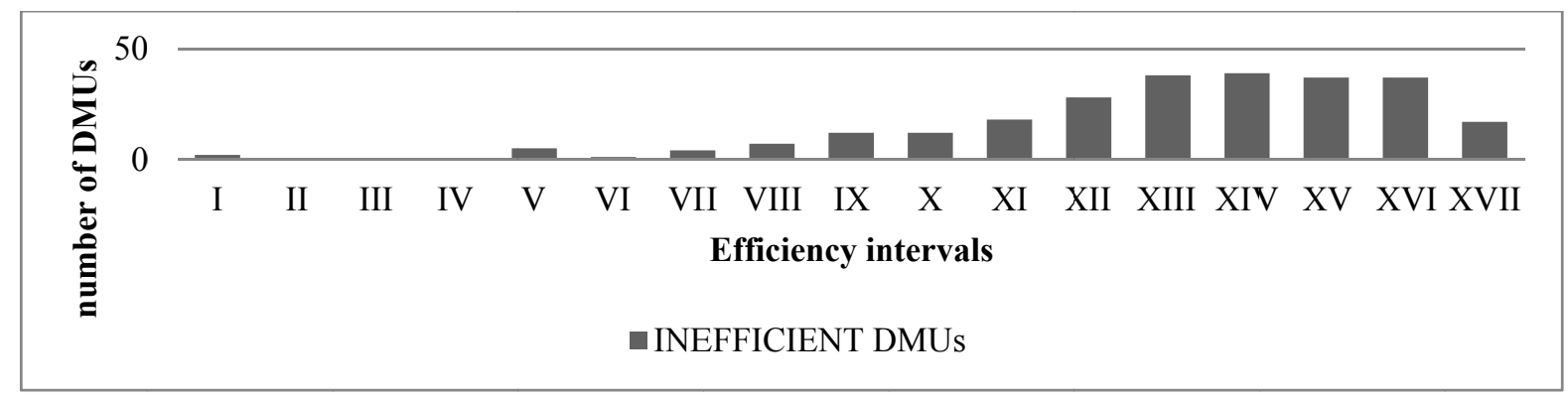

Source: Own elaboration. 
Table 4: Assignment of DMUs to intervals depending on the value of efficiency indicators for efficient DMUs

\begin{tabular}{|c|c|c|c|}
\hline \multirow{2}{*}{ No } & Lower bound & Upper bound & \multirow{2}{*}{$\begin{array}{c}\text { Number of } \\
\text { DMUs }\end{array}$} \\
\hline & \multicolumn{2}{|c|}{ [\%] } & \\
\hline 1 & $100,0 \%$ & $117,4 \%$ & 643 \\
\hline 2 & $116,0 \%$ & $133,4 \%$ & 409 \\
\hline 3 & $133,0 \%$ & $150,4 \%$ & 244 \\
\hline 4 & $150,0 \%$ & $167,4 \%$ & 143 \\
\hline 5 & $167,4 \%$ & $184,8 \%$ & 83 \\
\hline 6 & $184,8 \%$ & $202,2 \%$ & 67 \\
\hline 7 & $202,2 \%$ & $219,6 \%$ & 36 \\
\hline 8 & $219,6 \%$ & $237,0 \%$ & 33 \\
\hline 9 & $237,0 \%$ & $254,4 \%$ & 18 \\
\hline 10 & $254,4 \%$ & $271,8 \%$ & 14 \\
\hline 11 & $271,8 \%$ & $289,3 \%$ & 12 \\
\hline 12 & $289,3 \%$ & $306,7 \%$ & 6 \\
\hline 13 & $306,7 \%$ & $324,1 \%$ & 15 \\
\hline 14 & $324,1 \%$ & $341,5 \%$ & 8 \\
\hline 15 & $341,5 \%$ & $358,9 \%$ & 3 \\
\hline 16 & $358,9 \%$ & $376,3 \%$ & 4 \\
\hline 17 & $376,3 \%$ & $393,7 \%$ & 5 \\
\hline 18 & $393,7 \%$ & $411,2 \%$ & 1 \\
\hline 19 & $411,2 \%$ & $428,6 \%$ & 3 \\
\hline 20 & $428,6 \%$ & $446,0 \%$ & 2 \\
\hline 21 & $446,0 \%$ & $463,4 \%$ & 4 \\
\hline 22 & $463,4 \%$ & $480,8 \%$ & 0 \\
\hline
\end{tabular}

\begin{tabular}{|c|c|c|c|}
\hline \multirow{2}{*}{ No } & Lower bound & Upper bound & \multirow{2}{*}{$\begin{array}{c}\text { Number of } \\
\text { DMUs }\end{array}$} \\
\hline & \multicolumn{2}{|c|}{ [\%] } & \\
\hline 23 & $480,8 \%$ & $498,2 \%$ & 1 \\
\hline 24 & $498,2 \%$ & $515,6 \%$ & 0 \\
\hline 25 & $515,6 \%$ & $533,1 \%$ & 2 \\
\hline 26 & $533,1 \%$ & $550,5 \%$ & 2 \\
\hline 27 & $550,5 \%$ & $567,9 \%$ & 0 \\
\hline 28 & $567,9 \%$ & $585,3 \%$ & 1 \\
\hline 29 & $585,3 \%$ & $602,7 \%$ & 0 \\
\hline 30 & $602,7 \%$ & $620,1 \%$ & 2 \\
\hline 31 & $620,1 \%$ & $637,5 \%$ & 0 \\
\hline 32 & $637,5 \%$ & $655,0 \%$ & 0 \\
\hline 33 & $655,0 \%$ & $672,4 \%$ & 2 \\
\hline 34 & $672,4 \%$ & $689,8 \%$ & 0 \\
\hline 35 & $689,8 \%$ & $707,2 \%$ & 0 \\
\hline 36 & $707,2 \%$ & $724,6 \%$ & 0 \\
\hline 37 & $724,6 \%$ & $742,0 \%$ & 1 \\
\hline 38 & $742,0 \%$ & $759,4 \%$ & 0 \\
\hline 39 & $759,4 \%$ & $776,9 \%$ & 0 \\
\hline 40 & $776,9 \%$ & $794,3 \%$ & 1 \\
\hline 41 & $794,3 \%$ & $811,7 \%$ & 0 \\
\hline 42 & $811,7 \%$ & $829,1 \%$ & 0 \\
\hline 43 & $829,1 \%$ & $846,5 \%$ & 0 \\
\hline 44 & $846,5 \%$ & $863,9 \%$ & 1 \\
\hline
\end{tabular}

Source: Own elaboration.

Figure 2: Efficient DMUs - frequency chart

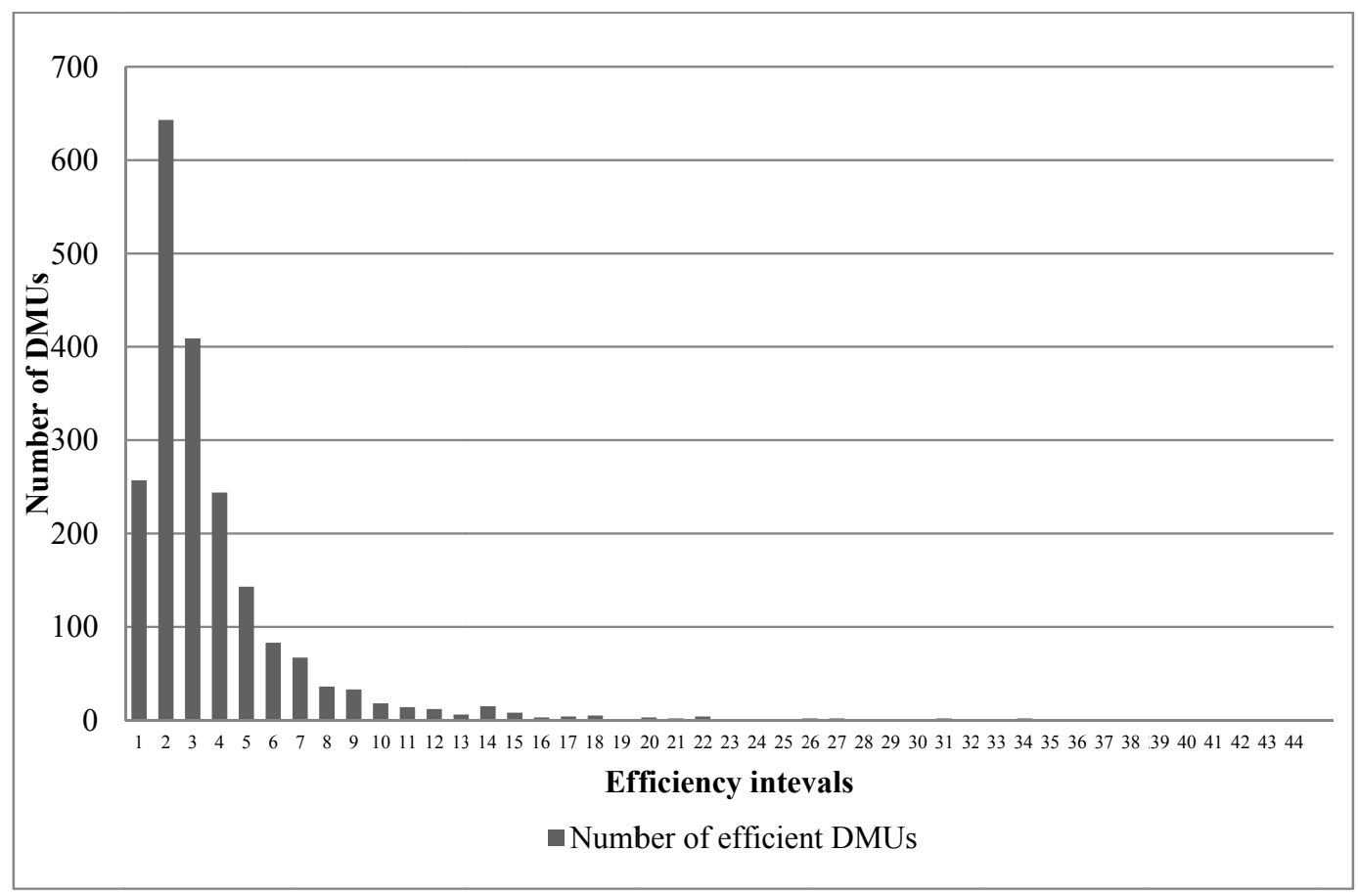

Source: Own elaboration. 
Figure 3: Inefficient municipalities

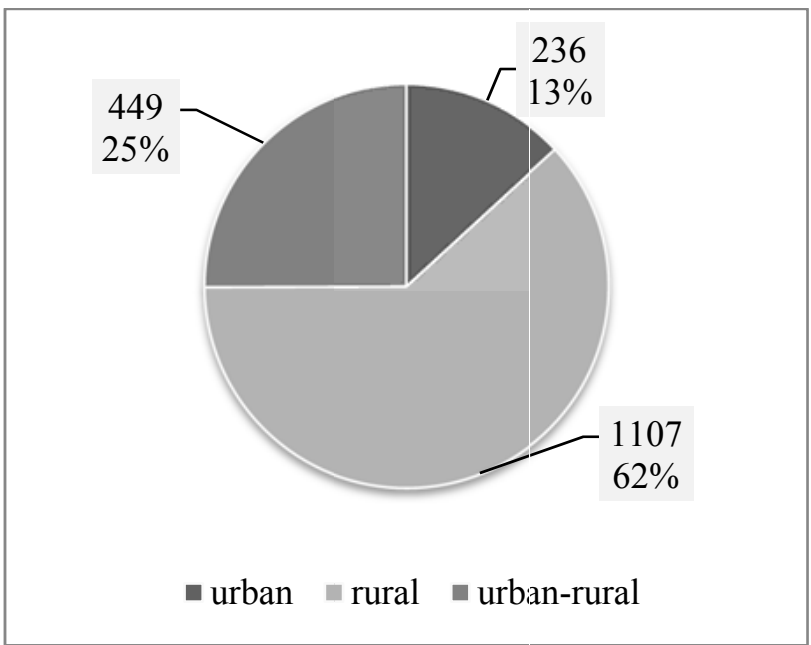

Source: Own elaboration.

While analyzing the efficiency of municipalities in terms of sustainable development by means of SECCR model some additional analyses can be conducted, e.g. benchmarking and target technology for an efficient DMU.

Firstly, the optimal technology of inefficient units has been calculated. Due to the limitations as to the size of the article, for the purposes of interpretation, the results were presented only for selected DMUs.
Figure 4: Efficient municipalities

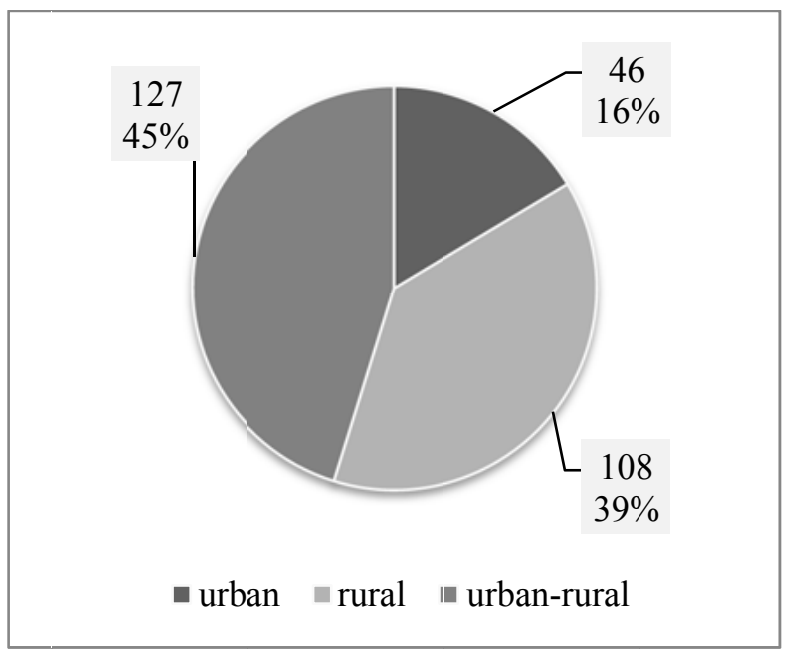

Source: Own elaboration.

While analyzing the efficiency of municipalities in terms of sustainable development by means of SECCR model some municipalities constitute benchmarks for others. All the inefficient units in order to improve their efficiency should follow the technological example of chosen benchmarks. The analysis of benchmarks constituted the next part of the study. The results of the study on benchmarks are described below and Figure 3 presents the results for selected

Figure 5: Benchmarking graph for the year 2016

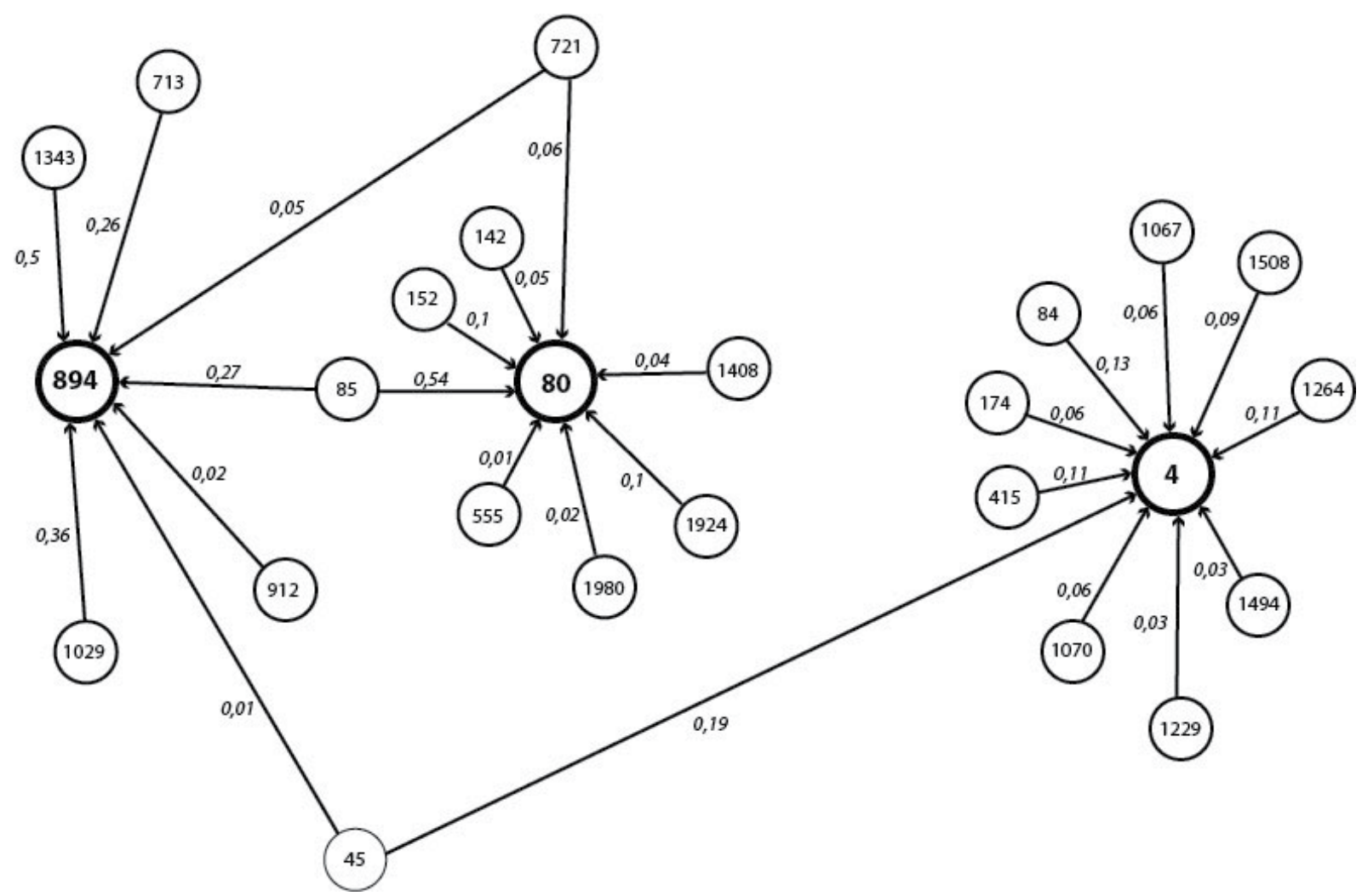

Source: Own elaboration based on Guzik (2009), p. 79. 
DMUs in the year 2016.

Considering benchmarking, one thinks of setting patterns (optimal technologies) for objects that are ineffective in the Farrell-Debreu's sense $(1951)^{3}$. The benchmarking graph is presented in Figure 4. There are exemplary 3 inefficient objects (DMUs) in the Farrell sense. On the basis of the graph, we note that object 45 is the pattern for all three ineffective DMUs. Considered DMUs have from 7 to 12 benchmarks. What is more, DMUs number 45 constitutes benchmark for all presented in the Figure 5 inefficient DMUs. In the whole study it is a benchmark for 85 inefficient DMUs.

In order to check which benchmark municipalities had greater or smaller impact on the optimal technology of inefficient units a detailed analysis was conducted in the year 2016. Table 5 presents the chosen results - optimal outputs municipality 894 in year 2016.
The optimal technologies, $\widehat{T}$, for rural-urban commune [1418023Konstancin-Jeziorna] have the following form:

$\widehat{\mathrm{T}}_{\text {[1418023 Konstancin-Jeziorna] }}=0,05 \mathrm{t}_{\text {[1211042 Czorsztyn] }}$

$+0,27 \mathrm{t}_{[0216062 \text { Radwanice }]}+0,01 \mathrm{t}_{0208133 \text { Stronie Śląskie }]}$

$+0,02 \mathrm{t}_{[1420021 \text { Raciąż }]}+0,36 \mathrm{t}_{[1601052 \text { Lubsza] }}$

$+0,26 \mathrm{t}_{[1210122 \text { Nawojowa] }}+0,5 \mathrm{t}_{\text {[2206072 Nowa Karczma] }}$

In order to present the complete analysis of the efficiency of sustainable development of [1418023Konstancin-Jeziorna] rural-urban commune the objective technology as a percentage of empirical one was presented.

The [1418023Konstancin-Jeziorna] rural-urban commune in terms of sustainable development should follow the example of [1211042Czorsztyn] in terms of $\{0\} 1188 \%$ and in terms of $\{0\} 2$ in $126 \%$. The similar analysis will be made in the future research for all inefficient DMUs.

Table 5: The calculation of the target technology for the rural-urban commune [1418023 Konstancin-Jeziorna]

\begin{tabular}{|c|c|c|c|c|c|c|c|c|c|c|c|c|c|c|c|c|c|}
\hline 突 & 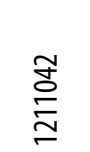 & 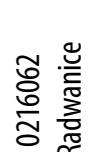 & 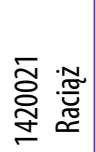 & 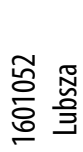 & 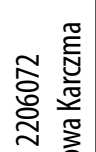 & 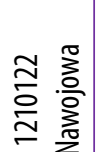 & 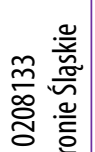 & \multicolumn{7}{|c|}{ Size implemented in the technology regime } & \multicolumn{2}{|c|}{$\begin{array}{c}\text { Target } \\
\text { technology }\end{array}$} & 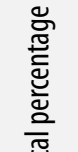 \\
\hline 䓂 & 능 & $\underset{\precsim}{\nwarrow}$ & 응 & $\stackrel{\text { }}{o}$ & $\tilde{a}$ & 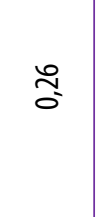 & ס & 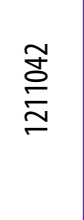 & 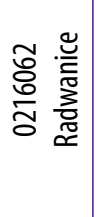 & 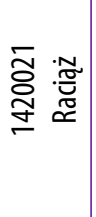 & 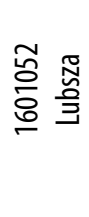 & 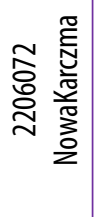 & 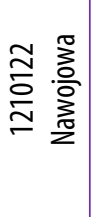 & 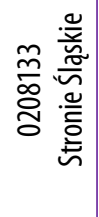 & . & 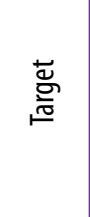 & 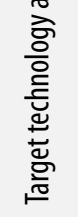 \\
\hline$\{0\} 1$ & 10,5 & 13,7 & 8,2 & 8,6 & 15,6 & 15,3 & 5,7 & 0,5 & 3,7 & 0,2 & 3,1 & 7,8 & 4,0 & 0,1 & 10,3 & 19,3 & $188 \%$ \\
\hline$\{0\} 2$ & 211,0 & 227,0 & 350,0 & 257,0 & 623,0 & 640,0 & 225,0 & 10,6 & 61,3 & 7,0 & 92,5 & 311,5 & 166,4 & 2,3 & 517,0 & 651,5 & $126 \%$ \\
\hline$\{0\} 3$ & 75,9 & 99,0 & 89,1 & 95,1 & 76,4 & 32,0 & 81,3 & 3,8 & 26,7 & 1,8 & 34,2 & 38,2 & 8,3 & 0,8 & 74,3 & 113,9 & $153 \%$ \\
\hline$\{0\} 4$ & 92,5 & 74,2 & 51,5 & 77,4 & 69,8 & 44,9 & 78,3 & 4,6 & 20,0 & 1,0 & 27,9 & 34,9 & 11,7 & 0,8 & 64,4 & 100,9 & $157 \%$ \\
\hline$\{0\} 5$ & 20,1 & 21,5 & 20,6 & 21,3 & 21,2 & 19,2 & 24,0 & 1,0 & 5,8 & 0,4 & 7,7 & 10,6 & 5,0 & 0,2 & 16,1 & 30,7 & $191 \%$ \\
\hline$\{0\} 6$ & 93,4 & 93,6 & 129,1 & 77,8 & 95,8 & 84,8 & 87,9 & 4,7 & 25,3 & 2,6 & 28,0 & 47,9 & 22,1 & 0,9 & 95,3 & 131,4 & $138 \%$ \\
\hline$\{0\} 7$ & 99,6 & 86,1 & 149,6 & 62,9 & 101,3 & 72,6 & 79,1 & 5,0 & 20,2 & 3,0 & 22,6 & 50,7 & 18,9 & 0,8 & 89,4 & 124,2 & $139 \%$ \\
\hline$\{0\} 8$ & 185,8 & 179,4 & 794,9 & 103,0 & 107,0 & 116,6 & 188,4 & 9,3 & 48,4 & 15,9 & 37,1 & 53,5 & 30,3 & 1,9 & 178,8 & 196,4 & $110 \%$ \\
\hline$\{0\} 9$ & 462,1 & 115,2 & 133,6 & 151,9 & 147,2 & 153,2 & 85,0 & 23,1 & 31,1 & 2,7 & 54,7 & 73,6 & 39,8 & 0,9 & 194,8 & 225,8 & $116 \%$ \\
\hline$\{0\} 10$ & 1923,2 & 162,1 & 3,0 & 191,3 & 2523,1 & 934,2 & 289,0 & 96,2 & 43,8 & 0,1 & 68,9 & 1261,6 & 242,9 & 2,9 & 313,0 & 1716,2 & $548 \%$ \\
\hline$\{0\} 11$ & 74,4 & 186,4 & 241,9 & 63,9 & 201,6 & 92,7 & 247,0 & 3,7 & 50,3 & 4,8 & 23,0 & 100,8 & 24,1 & 2,5 & 108,8 & 209,2 & $192 \%$ \\
\hline$\{0\} 12$ & 37,6 & 62,2 & 64,6 & 46,3 & 62,3 & 46,7 & 44,6 & 1,9 & 16,8 & 1,3 & 16,7 & 31,1 & 12,1 & 0,4 & 49,5 & 80,3 & $162 \%$ \\
\hline$\{0\} 13$ & 34,2 & 54,8 & 29,1 & 28,9 & 34,7 & 18,7 & 47,4 & 1,7 & 14,8 & 0,6 & 10,4 & 17,3 & 4,9 & 0,5 & 39,6 & 50,1 & $127 \%$ \\
\hline$\{0\} 14$ & 4085,4 & 5537,3 & 4793,7 & 3303,8 & 4983,1 & 3944,9 & 5112,2 & 204,3 & 1495,1 & 95,9 & 1189,4 & 2491,5 & 1025,7 & 51,1 & 5901,7 & 6552,9 & $111 \%$ \\
\hline
\end{tabular}

Source: Own elaboration. 


\section{CONCLUSION}

Let us recall that the main objective was to build the ranking of Polish municipalities using the Data Envelopment Analysis (DEA) including especially SECCR model, in the scope of sustainable development. The DEA method is one of the most frequently used methods in the literature on the subject of studying the effectiveness of a dark group of individuals. Its basic advantage, which is also a kind of premise for its application, is that as a non-parametric method, it does not require knowledge of the functional relationship between inputs and outcomes, because the efficiency curve is estimated on the basis of empirical data on the amount of inputs and effects. In addition, Data Envelopment Analysis is increasingly used in the world as a practical tool to support decision making in the management of organizations and business units. In other words, the results of the DEA aim at providing information to managers of self-governmental units as to their condition within the framework of the sustainable development indicator. It provides valuable guidance on how a given ineffective entity should conduct its policy to achieve results similar to those of effective units. However, when deciding to conduct a DEA inference, one should be aware of its limitations. In some studies, the problematic may be fact that DEA ignores statistical errors and the effect of exogenous variables on the operation. What is more, DEA is good at estimating relative efficiency of a DMUs but it converges gradually to absolute efficiency.

The results are following: $85 \%$ of studied municipalities are efficient while $15 \%$ of the analysed municipalities were classified as inefficient. Outcomes of our experiments show that it is possible to identify the ranking of efficiency of municipalities in terms of sustainable development. Using SE-CCR model some municipalities represent benchmarks for the others from research sample. Identified inefficient units should follow the technological example of model unit in order to develop their efficiency.

According to the list of advantages of DEA method (ability of marking non productivity for every input and output in all units, ideal approach for the large number of DMUs, inputs and outputs don't have to be equal) it should be underlined that this is the leader of non-parametric methods for measuring efficiency of organization. Using SE-CCR model to analyse the efficiency of Polish municipalities can be assumed as a benchmark for inefficient DMUs from research sample. All the inefficient units in order to develop their efficiency should follow the model DMU. Using given above formula inefficient DMUs will get very precise instruction how to obtain optimal outputs of model municipality.
To make comprehensive analysis we selected the shares of individual municipalities in categories according to the effective and ineffective DMUs. According to the inefficient DMUs $45 \%$ of units are rural-urban, $39 \%$ - rural and $46 \%$ urban, while efficient units have following structure: rural (62\%), $25 \%$ - urban-rural and the rest constitute urban units.

The findings of this analysis stimulate directions for further research. Conducted research study can be expanded by a panel data analysis based on e.g. DEA window analysis.

\section{Endnotes}

2 More details concerning the theoretical aspects of DEA models: Charnes (1994).

3 Farrell-Debreu's efficiency can be interpreted as the multiplicity to which an object should reduce its current inputs if it wants to achieve a 100\% efficiency. This efficiency belongs to the efficiency class based on a linear technological radius (radial efficiency). 


\section{REFERENCES}

Alsharif, K., Ferozb, E. H., Klemerc, A. and Raabd, R. 2008. Governance of water supply systems in the Palestinian territories: a data envelopment analysis approach to the management of water resources. Journal of Environmental Management 87: 80-94. DOI: https://doi. org/10.1016/j.jenvman.2007.01.008.

Andersen, P. and Petersen, N. C. 1993. A procedure for ranking efficient units in data envelopment analysis. Management Science 39 (10): 1261-1264. DOI: https:// doi.org/10.1287/mnsc.39.10.1261.

Banker, R. D., Charnes, A. andCooper, W. W. 1984. Some models for estimating technical and scale inefficiencies in data envelopment analysis. Management Science 30: 10781092. DOI: https://doi.org/10.1287/mnsc.30.9.1078.

Charnes, A., Cooper, W. W. and Rhodes, E. 1978. Measuring the efficiency of decision-making units. European Journal of Operational Research 2 (6): 429-444. DOI: https://doi.org/10.1016/0377-2217(78)90138-8.

Clark, G., Huxley, J. and Mountford, D. 2010. Organising local economic development: the role of development agencies and companies. OECD. DOI: https://doi. org/10.1787/9789264083530en.

Corrado lo Storto 2013. Evaluating technical efficiency of Italian major municipalities: a data envelopment analysis model. Procedia - Social and Behavioral Sciences 81 (2013): 346-350. DOI: https://doi.org/10.1016/j. sbspro.2013.06.440.

Czyż-Gwizdała, E. 2003. Conceptions of organizational efficiency measurement - the use of the DEA method in evaluating the organization efficiency. Zarządzanie i Finanse 11 (1): 103-116.

De Borger, B. and Kerstens, K. 1996. Cost efficiency of Belgian local governments: a comparative analysis of FDH, DEA and econometric approaches. Regional Science and Urban Economics 2: 145- 170. DOI: https:// doi.org/10.1016/0166-0462(95)02127-2.

De Sousa, S. and Cribari, M. 2005. Explaining DEA technical efficiency scores in an outlier corrected environment: the case of public services in Brazilian municipalities. Brazilian Review of Econometrics (25): 287-313. DOI: https://doi.org/10.12660/bre.v25n22005.2507.

Debreu, G. 1951. The coefficient of resource utilization. Econometrica 19 (3): 273-292. DOI: https://doi. org/10.2307/1906814.

Drew, J., Dollery, B. and Kortt, M. A. 2015. What determines efficiency in local government? A DEA analysis of NSW local government. Economic Papers A Journal of Applied Economics and Policy 34 (4): 243-256. DOI: http://doi. org/10.1111/1759-3441.12118.

Farrell, M. J. 1957. The measurement of productive efficiency. Journal of the Royal 28 Statistical Society
Series A (General) 120 (3): 253-290. DOI: http://doi. org/10.2307/2343100.

Geys, B. and Moesen, W. 2009. Measuring local government technical (in)efficiency: an application and comparison of FDH, DEA and econometric approaches. Public Performance and Management Review 32: 489-504. DOI: https://doi.org/10.2753/pmr1530-9576320401.

Guzik, B. 2009. Podstawowe modele DEA w badaniu efektywności gospodarczej i społecznej (Basic DEA models in the study of economic and social efficiency). Poznań: Wydawnictwo Uniwersytetu Ekonomicznego w Poznaniu.

Guzik, B. 2009. Propozycja metody szacowania efektywności instytucji non profit (A proposal a method for estimating the efficiency of non-profit institutions). Roczniki Ekonomiczne Kujawsko-Pomorskiej Szkoły Wyższej w Bydgoszczy2.

Hajduk, S. 2018. Efficiency evaluation of urban transport using the DEA method. Equilibrium. Quarterly Journal of Economics and Economic Policy 13 (1): 141-157. DOI: https://doi.org/10.24136/eq.2018.008.

Huang, C. H., Lin, Y. H. and Tseng, M. L. 2008. Application of cost benefit analysis and data envelopment analysis to evaluate the municipal solid waste management projects in metro Manila'. Wseas Transactions On Business And Economic 12 (5): 524-540. ISSN: 1109-9526.

Jacobs, R., Smith, P. C. and Street, A. 2013. Mierzenie efektywności w ochronie zdrowia (Measuring the efficiency in the Healthcare) . Warszawa: ABC Wolters Kluwer Business.

Jewczak, M. and Żółtaszek, A. 2011. Ocena efektywności technicznej podmiotów sektora opieki zdrowotnej w Polsce w latach 1999-2009 w ujęciu przestrzenno-czasowym na przykładzie szpitali ogólnych (Assessment of technical efficiency of healthcare sector entities in Poland in the years 1999-2009 in space-time perspective on the example of public hospitals). Problemy Zarządzania, 9 (3): 194-210. ISSN 1644-9584.

Kirigia, J. M., Emrouznejad, A., Cassoma, B., Asbu, E. Z. and Barry, S. 2008. A performance assessment method for hospitals: the case of municipal hospitals in Angola. Journal of Medical System 32 (6): 509-519. DOI: https:// doi.org/10.1007/s10916-008-9157-5.

Kobiałka, A., Kubik, R. (2018). Efficiency of the investment activity of Polish communes in rural areas. Proceedings of the 8th International Scientific Conference Rural Development 2017.

Kisman, Z. A. and Tasar, I. 2014. The key elements of local development. Procedia Economics and Finance Volume 15: 1689 - 1696. DOI: https://doi.org/10.1016/ S2212-5671(14)00642X.

Kudła, J. 2011. Zastosowanie analizy obwiedni danych do badań jakości usług ze szczególnym uwzględnieniem sektora bankowego (The use of data envelopment 
analysis to examine the quality of services with particular emphasis on the banking sector). Ekonomia 11:46-63. Mehrabian, S. A., Alirezaee, A. and Jahanshahloo, G. R. 1999. A complete efficiency ranking of decision-making units in DEA. Computational Optimization and Applications (COAP), 14: 261-266.

Miszczyński, P. M. 2013. Measuring the efficiency of local government units management in the central region of Poland in a dynamic perspective. Quantitative Methods in Economics, XIV (2): 108 - 117.

Murillo-Zamorano, L. R. 2004. Economic efficiency and frontier techniques. Journal of Economic Surveys 18(1):33-77. DOI: https://doi.org/10.1111/j.1467-6419.2004.00215.x.

Myna, A. 1998. Rozwój lokalny, regionalne strategie rozwoju, regionalizacja (Local development, regional development strategies, regionalization). Samorząd Terytorialny No 11: 30-48.

Łękawa, Z. 2012. Ocena efektywności gmin województwa dolnośląskiego $z$ wykorzystaniem metody DEA (Evaluation of the effectiveness of communes in the Lower Silesian Voivodship using the DEA method). Annales Universitatis Mariae Curie-Skłodowska. Sectio H, Oeconomia 4 (2012): 515-526.

Nijkamp, P. and Suzuki, S. 2009. A generalized goals-achievement model in data envelopment analysis: an application to efficiency improvement in local government finance in Japan. Spatial Economic Analysis (4): 249-274. DOI: https://doi.org/10.1080/17421770903114687.

Nowak, M. 2015. Prakseologiczna ocena użyteczności metody DEA w diagnozie efektywności organizacji (Praxeological assessment of the usefulness of the DEA method in the diagnosis of organizational effectiveness). Zeszyty Naukowe Politechniki Poznańskiej, 66:101-112.

Pereira, H. andMarques, R. C. 2017. An analytical review of irrigation efficiency measured using deterministic and stochastic models. Agricultural Water Management 184: 28-35. DOI: https://doi.org/10.1016/j.agwat.2016.12.019.

Ramanathan, R. 2003. An Introduction to Data Envelopment Analysis: a Tool for Performance Measurement. New Delhi: Sage Publications.

Seiford, L. M. and Zhu, J. 1999. Infeasibility of super-efficiency data envelopment analysis. INFOR 37 (2): 174-187. DOI: https://doi.org/10.1080/03155986.1999.11732379.

Shanling, L., Jahanshahloob, G. R. and Khodabakhshic, M. 2007. Super-efficiency model for ranking efficient units in data envelopment analysis. Applied Mathematics and Computation 184 (2): 638-648. DOI: https://doi. org/10.1016/j.amc.2006.06.063.

Sierak, J. 2016. The role of local government in the process of stimulating the development of the local economy. Journal of Management and Financial Sciences 25 (9): 61-82.

Storto, C. L. 2016. Ecological efficiency based ranking of cities: a combined DEA cross efficiency and shannon's entropy method. Sustainability 8: 124. DOI: https://doi. org/10.3390/su8020124.

Sztando, A. 1998. Oddziaływanie samorządu lokalnego na rozwój lokalny w świetle ewolucji modeli ustrojowych gmin (The impact of local government on local development in the light of the evolution of communal system models). Samorząd Terytorialny 11: 12-29.

Tone, K. 2001. A slakes-based measure of efficiency in data envelopment analysis. European Journal of Operational Research 130: 498-509.

Olejniczak, J. 2019. Efficiency vs. the level of per capita income of urban-rural municipalities in Poland. E-Finanse : Financial Internet Quarterly 15 (1)Z; 20-29.

Opolski, K., Podgórska, J. and Leśniowska-Gontarz, M. 2018. Quality criterion in measuring the efficiency of health facilities. Journal of Management and Financial Sciences 35 (2018): 81-92.

Vitezić, N. N., Šegota, A. A. and Setnikar-Cankar, S. S. 2016. Measuring the efficiency of public health services by DEA. International Public Administration Review 14 (4): 27-48. DOI: https://ssrn.com/abstract=3002377.

Worthington, A. 1999. Performance indicators and efficiency measurement in public libraries. The Australian Economic Review 32 (1): 31-42. DOI: https://doi. org/10.1111/14678462.00091.

Yang, W., Lee, Y. and Hu, J. 2016. Urban sustainability assessment of Taiwan based on data envelopment analysis. Renewable and Sustainable Energy Reviews (61): 341-353.DOI: https://doi.org/10.1016/j.rser.2016.04.015.

Yuan, X., Wang, Q., Wang, K., Wang, B., Jin, J. and Wei, Y. 2015. China's regional vulnerability to drought and its mitigation strategies under climate change: data envelopment analysis and analytic hierarchy process integrated approach. Mitigation and Adaptation Strategies for Global Change 20: 341. DOI: https://doi.org/10.1007/ s11027-013-9494-7.

Ziębicki, B. 2014. Efektywność organizacyjna podmiotów sektora publicznego (Organizational efficiency of public sector entities). Kraków: Wydawnictwo Uniwersytetu Ekonomicznego w Krakowie.

Zioło, M. 2012. Modele polityki inwestycyjnej gmin i ich wpływ na rozwój przedsiębiorczości (Municipal investment policy models and their impact on entrepreneurship development). Ekonomiczne Problemy Usług 97 (2012): 283-293. 